\title{
Clinical behavior of children with Infantile Cerebral Palsy after Ozone therapy
}

\author{
Benjamin Arenas ${ }^{1}$, Jose Luis Calunga ${ }^{1}$, Silvia Menendez-Ceperoํ, Carmen Vera², Mariela Infante ${ }^{3}$, \\ Manuel Herrera4, Olga Franco², Alicia Angela Gorzalewski ${ }^{5}$ \\ ${ }^{1}$ National Center for Scientific Research, Ozone Research Center. Havana, Cuba, ${ }^{2 K a w s a y ~ O z o n e ~ I n s t i t u t e, ~ P e r u, ~}{ }^{3}$ Neurosurgery \\ Department, Juan Manuel Márquez Pediatric Hospital. Havana, Cuba, ${ }^{4}$ Ozone Center, Mexico, 5 Infectology Hospital of CMN La \\ Raza, Mexico
}

\section{(2) OPEN ACCESS}

\section{Citation}

Arenas B, Calunga JL, MenendezCepero S, Vera C, Infante M, Herrera $\mathrm{M}$, et al. Clinical behavior of children with Infantile Cerebral Palsy after Ozone therapy. J Ozone Ther. 2019:2(3)

doi: 10.7203/jo3t.2.3.2018.11205

\section{Academic Editor}

Jose Baeza-Noci,

School of Medicine, Valencia University, SPAIN

\section{Editor}

World Federation of Ozone Therapy, Bologna, ITALY

\section{Received}

December 16, 2017

\section{Accepted}

December 16, 2017

\section{Published}

December 15, 2018

\section{Intellectual Property}

Arenas B.

This is an open access article distributed under the terms of the Creative Commons Attribution License (CC BY 4.0), which permits unrestricted use, distribution, and reproduction in any medium, provided the original author and source are credited.

\section{Author Information}

benxad72@gmail.com

\section{ABSTRACT}

Objective: The aim of this study was to determine the usefulness of ozone therapy in the treatment of Infantile Cerebral Palsy (ICP).

Patients and methods: A non-controlled clinical assay was made in the Ozone Research Center (CIO), Havana, Cuba from January 2013 to January 2014. The sample was constituted by patients remitted to pediatrics consultation of $\mathrm{CIO}$, to whom inclusion and exclusion criteria were applied. The study group involved 45 patients, from 1 month of birth to 8 years, with cerebral palsy of hypoxic-ischemic cause. The evaluation criteria were: evolution of the motor disorder according to the Gross Motor Function Classification System (GMFCS) scale, modification of muscle tone (Ashworth modified scale) and response to treatment (O'Brien modified scale). The way of administration was rectal insufflation; concentrations between 15, 20, 25 and $30 \mathrm{mg} / \mathrm{L}$ were used, volumes varied according to age, making calculation of the dose of ozone according to kilograms of weight. Cycles of 20 sessions, every 3 months were indicated, until completing 4 in 16 months. Patients were clinically evaluated, according to the scales used, before and after each cycle.

Results and Discussion: The best answer to treatment was obtained in the group aged $\leq 4$ years. The variables analyzed showed a significant improvement when the ozone treatment concluded. With respect to the evolution of the motor disorder, in $65 \%$ of cases it improved. In the group of children below 4 years, the response was better in relation to the muscle tone. Response to treatment, according to the relatives' criteria, was of $70 \%$ of the children with marked improvement in the tone and muscle function.

Conclusions: The greatest percentage of patients improved in the evolution of the motor disorder; when the Manual Ability Classification System (MACS) scale was applied, more than half the patients showed an improvement. A high percentage of children get a satisfactory result regarding muscle tone and motor function. No side effects were present in any of the cases during the study.

Keywords: Ozone therapy, infantile cerebral palsy, rectal insufflation, muscle tone and muscle function, O'Brien scale 


\section{Introduction}

Infantile Cerebral Palsy (ICP) is a descriptive term historically used to group, with therapeutic, epidemiologic and administrative objectives, diverse motor and postural disorders causing limitation in the activity, attributed to nonprogressive disorders that occurred in the brain developing during fetal stage or early infantile stage [1, 2]. Its prevalence is between 1.5 and 3 per 1,000 born alive. It is generally classified as congenital or acquired, according to the time when the brain damage occurred [3-7].

Motor syndromes are evident by alterations of posture, of voluntary movements and reflexes, which leads to development of a significant physical disability. These patients present with other alterations of neurodevelopment (convulsions, psychomotor and language slowness, disorders in learning, paying attention and conduct) in different degrees. Clinical manifestations vary according to age of conception, etiology and localization of lesions or anomalies [8)].

Pathologies associates to ICP are produced before, during or after birth all the same. Approximately $35 \%$ of those occurring during birth are due to hypoxia-ischemia $(\mathrm{HI})$, but only between 12 and $23 \%$ develop moderate or serious ICP $[9,10]$. Those neonates older than 34 weeks gestation who develop ICP of spastic or diskinetic quadriplegia type due to a hypoxiaischemic lesion during birth must present the following evidences:

1. Metabolic acidosis during birth, in the fetus or in arterial blood of the umbilical cord or peripheral blood at birth $(\mathrm{pH}<7$, deficit of bases $>16$ $\mathrm{mM} / \mathrm{L})$.

2. Moderate or serious encephalopathy in the first $24 \mathrm{~h}$ of life.

Other factors supporting diagnosis of neonatal encephalopathy due to $\mathrm{HI}$ during birth are:

1. Presence during birth of a sentinel hypoxic event (rupture of uterus, detachment of placenta, prolapse of the cord, embolism of amniotic liquid, fetal transfusion due to previous vessels or fetal-maternal hemorrhage).

2. Rapid and sustained deterioration of fetal cardiac rate during the sentinel hypoxic event in a fetus with previous normal heart rate.

3. Apgar score from 0 to 6 for more than 5 minutes.

4. Early effect on other organs.

5. Evidences in magnetic resonance (MR) of early cerebral $\mathrm{HI}$ - early cerebral edema between 6-12 hours and, mainly, on 4 days of age in the majority of cases at terminus [11-14].

Infantile Cerebral Palsy (ICP) is an important health problem which generates great disability in childhood. There are multiple therapeutic alternatives [15-18], however, there is scarce available literature to support indication of different therapies for neurorehabilitation and that could aid clinical physicians in recommending them to parents.

Despite medical advances in the fields of obstetric and perinatal medicine, unfortunately, there is no preventive or healing treatment for ICP. Therefore, impossibility to avoid irreversible cerebral lesions in new born with hypoxic ischemic encephalopathy and improve clinic alterations of patients with ICP has motivated development of this research to evaluate the efficacy and safety of ozone therapy as alternative treatment in comprehensively dealing 
with the patient's Static Lesions of the central nervous system (CNS), taking as basis the preclinical and clinical studies carried out in diverse pathologies where the ischemia/reperfusion phenomenon has been present and beneficial results have been obtained, making possible the use of ozone, due to its biologic properties, in patients with Cerebral Palsy to improve their quality of [19-24].

\section{Patients and methods}

A non-controlled clinical assay was carried out in the Ozone Research Center (CIO) from January 2013 to January 2014.

The study was evaluated by an institutional scientific council and ethics committee, also follow the criteria of declaration of Helsinki.

The sample was made up of patients referred to pediatrics consultation of $\mathrm{CIO}$, to whom the inclusion (children between 1 month and 8 years of age with infantile cerebral palsy of hypoxic-ischemic cause and signed consent of parents to be part of the study) and exclusion criteria (infantile cerebral palsy of other causes, acute infectious diseases, convulsive status) were applied.

Children between 1 month and 8 years with infantile cerebral palsy of hypoxic-ischemic cause remained in the study group. Their parents gave their signed consent being the group constituted by 45 patients.

Ozone administration was by rectal way; concentrations between 15, 20, 25 and $30 \mathrm{mg} / \mathrm{L}$ were used, volumes varied according to the patient's weight. The ozone dose was obtained multiplying a constant of $0.05 \mathrm{mg} / \mathrm{kg}$ by the weight in kilograms of the patient. With this ozone dose and knowing the ozone concentration, is it possible to calculate the ozone volume. Cycles of 20 sessions, 5 session per week, until finish the 20 session; then were indicated 3 free months to completing 4 cycles in 16 months. Patients were evaluated clinically according to the scales used before and after each cycle.

The analyzed variables were:

1. Evolution of motor disorder according to the Gross Motor Function Classification System scale (GMFCS)

2. Evolution of patient according to the manua ability classification scale

3. Modification of muscle tone (Ashworth modified scale)

4. Response to treatment (O'Brien modified scale)

Evaluation criteria were the following:

For variables 1, 2 and 3

- Same: When no improvement was registered according to the scale

- Improved: Patients that showed some progress according to the measured scale

For variable 4

- No changes in muscle tone

- Slight improvement of muscle tone

- Slight improvement of tone and muscle function

- Significant improvement of tone and muscle function

- Significant improvement of tone and muscle function for more than 12 months 
Statistical analysis was made by percentage analysis, the data base was included and analyzed in a contingence tables, using the software, Statistical Package for the Social Sciences version 15.0 (SSPS).

\section{Results}

As shown in table 1, a $71.1 \%$ of children improved their classification in the Gross Motor Function Classification System scale, which demonstrates that they improved their motor deficit in the clinical exam, achieving a better score in the classification scale due to their motor deficit improvement.

Table 1. Evolution of children with ICP according to GMFC classification.

\begin{tabular}{lcc} 
Criteria & No. of patients & $\%$ \\
\hline Same & 13 & 28.8 \\
Improved & 32 & 71.1 \\
Total & 45 & 100
\end{tabular}

Source: Database

In table 2 we can see how children evolved with this disorder according to manual abilities when carrying out the physical exam. A $46.7 \%$ remained the same and $53.3 \%$ improved with respect to their manual abilities. They did not show significant differences related to these percentages, only a trend to improve.

Table 2. Evolution of children with ICP according to manual ability scale.

\begin{tabular}{lcc} 
Criteria & No. of patients & $\%$ \\
\hline Same & 13 & 28.8 \\
Improved & 32 & 71.1 \\
Total & 45 & 100
\end{tabular}

Source: Database

Analyzing table 3 , we can observe that $66.7 \%$ of the children under study improved muscle tone in agreement with the degree classification of Ashworth, clinically explored by muscle motility, strength, tone and trophy, only $33.3 \%$ remained in the same scale according to their muscle tone. 
Table 3. Evolution of children with ICP according to Ashworth scale referring to muscle tone.

\begin{tabular}{lcc} 
Criteria & No. of patients & $\%$ \\
\hline Same & 15 & 33.3 \\
Improved & 30 & 66.7 \\
Total & 45 & 100 \\
\hline
\end{tabular}

Source: Database

Table 4 shows the evolution of tone and muscle function in these children, taking into account the parents and physiotherapists' criteria. There we can see that $46.7 \%$ of children had a significant improvement of the tone and muscle function and only $11.1 \%$ maintained without changes in this variable, which backs our hypothesis of evolution related to rehabilitation of the child with infantile cerebral palsy.

Tabla 4. Evolution of children with ICP according to O'Brien scale referring to response to treatment

\section{Criteria}

No change

Slight improvement in muscle tone

Slight improvement in muscle tone and function

Significant improvement in muscle tone and function

Significant improvement in tone and function in more than 1211 months

Total

$\begin{array}{ll}\text { No. of patients } & \% \\ 5 & 11.1 \\ 3 & 6.7 \\ 5 & 11.1 \\ 21 & 46.7 \\ 11 & 24.4\end{array}$

45

\section{Discussion}

In Infantile Cerebral palsy we must bear in mind that brain damage is produced by decrease of blood flow to the encephalon affects neurons of different brain areas which intervene in the motor control. These are: primary control area of movement (Pyramidal System), movement modulation centers (Basal Ganglions) and the Cerebellum [25].

Damage to this group of neurons as a whole, at clinical level evidences diverse anomalies in motor control. It can be observed that movement is affected causing tremor, dyskinesia, dystonia and [25].

Encephalon has a blood flow of 45 to 55 milliliters per minute per 100 grams of weight for white substance; it has 70 to 90 milliliters per minute per 100 
grams for grey substance. This shows that metabolic activity of the brain tissue depends on a great extent of oxygen contribution making this tissue very vulnerable to hypoxia $[25,26]$.

In our study, patients included proved a diagnosis of Infantile Cerebral Palsy of Hypoxic-Ischemic cause. For the result analysis, we must take into account some aspects of physiopathology of cerebral ischemia. For example, during cerebral ischemia, production of adenosine triphosphate (ATP) is reduced affecting the activity of Calcium ATP-ase enzyme. As a result, there is an abnormal increase of concentrations of this ion within the neuron leading to the release of excitatory neurotransmitters, such as glutamate (greatly responsible for excitotoxicity phenomena), release of free radicals in the ischemic cerebral tissue and inhibition of ATP production [27]. It is known that during cerebral ischemia there is production of abnormal high concentrations of reactive oxygen species (ROS), among which are the superoxide anion (O2.-), the hydroxyl radical $(\mathrm{OH}-)$, nitric oxide (NO) and peroxynitrite anion (ONOO-); all of them involved in neurodamage occurring during ischemia $[27,28]$. Also, in cerebral ischemia there is overstimulation of phospholipase A2, responsible of increase of degradation products of membrane phospholipids. These products accumulate and can turn into a platelet activating factor with an enhancement effect of platelet aggregation and inducer of inflammatory response by means of leukocytes adhesion and aggregation, hindering the passage of the blood flow to the encephalon [28].

In addition, during decrease of cerebral blood flow an inflammatory gene expression is induced in different types of cells causing release of proinflammatory cytokines [27-28]. Interleukin 1- $\beta$ (IL- $\beta$ ) and tumor necrosis factor a (TNF-a) are the cytokines that start the inflammatory response and interleukin 6 (IL-6) is the one that mediates the late inflammatory response in ischemic cerebral tissue [29]. IL-6 and TNF-a stimulate production of metalloproteinase, specifically the MMP-9. This metalloproteinase is responsible for alteration of the blood-brain barrier conditioning the occurrence of vascular edema and contributing to hemorrhagic transformation of infarct [29].

Beginning with the interpretation of the results obtained, for quantitative description of the motor function, in our study we used the GMFCS classification system, a tool that determines the degree of motor function limitation of patients with ICP $[30,31]$.

With respect to distribution at encephalic level of some antioxidants, it is known that vitamin E concentration in the cerebellum is low. On the other hand, it has been demonstrated that antioxidant enzymes like catalase have a lower concentration in the brain in relation to other tissues.

The most studied excitotoxin is glutamate. In physiologic conditions it is an excitatory neurotransmitter. However, excessive levels turn out to be toxic and determine the death of retinal ganglion cells [30]. The term excitotoxicity is stamped to describe this effect (Exciter + toxic $=$ Excitotoxin) [31].

A high local concentration of glutamate stimulates receptors of the cell surface, mainly the N-methyl-D-aspartate (NMDA), which opens the calcium channels, determining an intracellular overcharge of this ion with the subsequent activation of the nitric oxide synthase enzyme, which generates the nitric oxide with free radical properties. Glutamate, as well as nitric oxide, are neurotransmitters in normal conditions. However, when NMDA receptors are hyper stimulated, the nitric oxide combines with reactive mediators to oxygen generating peroxynitrates that produce nitrosylation and fragmentation of DNA [32]. 
With respect to spasticity, bulbar reticular formation inhibits the muscle tone, the inhibitory bulboreticular region receives orders from the motor cortex, anterior lobule of cerebellum and the basal ganglions. The exciter way of muscle tone is the medial reticule spinal fascicle from the bridge, that is, from reticular formation of the bridge.

There must be a balance between the excitatory and inhibitory ways of the muscle tone. For example, a lesion in the cortical-bulbar fibers at cortex level, or in an internal capsule it reduces inhibition of the muscle tone, in which a supremacy of the excitatory ways is produced with occurrence of spasticity [28-30,33].

Ozone oxidative pre/post-conditioning is an ozone's mechanism of action which has been demonstrated from experimental and clinical point of view [34-45]. Ozone therapy promotes a slight and transient oxidative stress through its capacity to "trigger" antioxidant endogenous system in order to re-establish antioxidant/pro-oxidant balance preserving mitochondrial integrity and superoxide dismutase activities [37,39]. Ozone is able to reestablished the cellular redox balance with a significant reduction in oxidative stress, which is one of the main processes unleashing the pathological cascade that induces protein injury in cerebral palsy of hypoxic-ischemic cause. On the other hand, the decrease in phospholipase A2 (PLA2) activity after ozone treatment suggests the reduction in inflammatory mediators produced in the arachidonic acid cascade $[19,20$, $22,23]$. Ozone protected against protein damage through regulation of ROS, preserving mitochondrial integrity and functionality [37,42]. Moreover, in experimental models studied, levels of nitric oxide, pro inflammatory cytokines, like the tumor necrosis factor (TNF- a) and interleukin 1 and 6, protease calcium-dependent activity, as well as overexpression of nuclear factor-kappa-B activity, were able to be modulated by ozone treatment $[36,38-40,43]$. Another aspect to be taken in consideration is the role of ozone in activating A1 adenosine receptors [21]. Adenosine, acting on presynaptic $A 1$ receptors, is able to inhibit glutamate release at excitatory synapses and, thus counteracts the neuronal hyper excitability that occurs during cerebral ischemia and spasticity [1,46-48]. Ozone's beneficial effects suggest that ozone is able to achieve a balance between $\gamma$-aminobutyric acid (GABA), the primary inhibitory neurotransmitter, and glutamate, the major excitatory neurotransmitter $[49,50]$.

All these physiopathologic mechanisms associated to infantile cerebral palsy of hypoxic-ischemic cause explain the positive results in our patients after the ozone treatment mainly based on its effect, a stimulant of the antioxidant defense system of the organism, improving the oxygen contribution to the brain tissue and to the rest of the body by increasing the blood flow and acting as a neuroprotective agent.

\section{Conclusions}

It was observed that the highest percentage of patients improved in the evolution of motor disorder according to the Gross Motor Function Classification scale. At applying the Manual Ability Classification System (MACS) scale, more than half the patients evidenced an improvement. On the other hand, the highest percentage of patients showed a significant improvement in muscle tone and motor function. No side effects were observed during the study. We recommend the application of Ozone therapy in the rehabilitation of children with cerebral palsy of hypoxic-ischemic cause and also in order to encouraging the results of this study support further confirmatory clinical trials. 


\section{References}

1. Bax M, Goldstein M, Rosenbaum P, Leviton A, Paneth N, Dan B, et al. Proposed definition and classification of cerebral palsy. Dev Med Child Neurol. 2005;47(8):574-576.

2. Robaina-Castellanos G, Riesgo-Rodriguez S, Robaina-Castellanos MS. Evaluacion diagnostica del niño con paralisis cerebral [Diagnostic evaluation of the child with cerebral palsy]. Rev Cubana Pediatr. 2007;79(2). Available from: http://bvs.sld.cu/revistas/ped/vol79_02_07/ ped07207.htm

3. Clark SL, Hankins GD. Temporal and demographic trends in cerebral palsy. Fact and fiction. Am J Obstet Gynecol. 2003;18(3):628-633.

4. Himmelmann K, Hagberg G, Beckung E, Hagberg B, Uvebrant P. The changing panorama of cerebral palsy in Sweden. IX. Prevalence and origin in the birth-year period 1995-1998. Acta Paediatr. 2005;94(3): 287-294.

5. Platt MJ, Krageloh-Mann I, Cans C. Surveillance of Cerebral Palsy in Europe. Prevalence and characteristics of children with cerebral palsy in Europe. Dev Med Child Neurol. 2002;44(9):633-640.

6. Gainsborough M, Surman G, Maestri G. Validity and reliability of the guidelines of the Surveillance of Cerebral Palsy in Europe for the classification of cerebral palsy. Dev Med Child Neurol. 2008;50:828-831.

7. Robaina-Castellanos GR, Riesgo-Rodriguez S, Robaina-Castellanos MS. Definicion y clasificacion de la paralisis cerebral: ¿un problema ya resuelto? [Definition and classification of cerebral palsy: a problem already solved?]. Rev Neurol. 2007;45(2):110-117.

8. Papazian O, Alfonso I. Tratamiento de la paralisis cerebral [Treatment of cerebral palsy]. Rev Neurol. 1997;25:728-739.

9. Blair E, Stanley FJ. Intrapartum asphyxia: a rare cause of cerebral palsy. J Pediatr. 1988;112:515-519.

10. Nelson KB, Grether JK. Potentially asphyxiating conditions and spastic cerebral palsy in infants of normal birth weight. Obstet Gynecol. 1998;179:507-513.

11. MacLennan A. A template for defining a causal relation between acute intrapartum events and cerebral palsy: international consensus statement. BMJ. 1999;319:1054-1059.

12. Kuban KC, Leviton A. Cerebral palsy. N Engl J Med. 1994;330:188-195.

13. Kleinsteuber-Saa K, Avaria-Benapres M, Varela-Estrada X. Actualizacion en paralisis cerebral infantil [Update in child cerebral palsy]. Rev Pediatr. 2014;11(2):1-3.

14. Santamaria JP, Williams ET, Desautels DA. Hyperbaric oxygen therapy in pediatrics. Adv Pediatr. 1995;42:335-366.

15. Tibbles PM, Edelsberg JS. Hyperbaric-oxygen therapy. New England J Med. 1996;334:1642-1648.

16. Kitago T, Krakauer JW. Motor learning principles for neurorehabilitation. Handb Clin Neurol. 2013;110:93-103. doi: 10.1016/ B978-0-444-52901-5.00008-3.

17. Mattern-Baxter K. Effects of a Group-Based Treadmill Program on children with neurodevelopmental impairment who are not yet 
ambulating. Pediatr Phys Ther. 2016;28(3):312-9. doi: 10.1097/PEP. 0000000000000250.

18. Ferre CL, Brandao MB, Hung YC, Carmel JB, Gordon AM. Feasibility of caregiver-directed home-based hand-arm bimanual intensive training: $A$ brief report. Dev Neurorehabil. 2015;18(1):69-74. doi: 10.3109/17518423.2014.948641.

19. Menendez S, Leon OS, Fernandez JL, Copello M, Weiser MT. Advances of Ozone Therapy in Medicine and Dentistry. La Habana: Palacio de las Convenciones; 2016.

20. Candelario E, Mohammed-Al-Dalain S, Leon OS, Menendez S, Perez G, Merino $\mathrm{N}$, et al. Oxidative preconditioning affords protection against carbon tetrachloride-induced glycogen depletion and oxidative stress in rats. J Appl Toxicol. 2001;21:297-301. doi: 10.1002/jat.75.

21. Leon OS, Ajamieh HH, Berlanga J, Menendez S, Viebahn R, Re L, et al. Ozone oxidative preconditioning is mediated by A1 Adenosine receptors in a rat model of liver ischemia/reperfusion. Transpl Int. 2008;21:39-48. doi: 10.1111/j.1432-2277.2007.00568.x.

22. Calunga JL, Menendez S, Barber E, Merino N, Cruz E. Ozone biological response in kidneys of rats submitted to warm ischemia. Ozone Sci Eng. 2003;25(3):233-240.

23. Barber E, Menendez S, Leon OS, Barber MO, Merino N, Calunga JL, et al. Prevention of renal injury after induction of ozone tolerance in rats submitted to warm ischemia. Mediators Inflamm. 1999;8(1):37-41. doi: 10.1080/09629359990702.

24. Calunga JL, Zamora Z, Borrego A, del Rio S, , Barber E, Menendez S, et al. Protective Effect of ozone/oxygen mixture on rats submitted to subtotal nephrectomy: role of antioxidant system. Mediators Inflamm. 2005;2005(4):221-227. doi: 10.1155/MI.2005.221.

25. Rany M, Aparecida A, Dupas G. Interaction with children with cerebral palsy: communication and stigma. Esc Anna Nery. 2014;18(1):47-53. Available from: http://www.scielo.br/pdf/ean/v18n1/en_1414-8145ean-18-01-0047.pdf

26. Sobrado M, Moro MA, Hurtado O. El papel de la glia tras la isquemia cerebral [Role of glia after brain ischemia]. In: Montaner J. Fisiopatologia de la isquemia cerebral [Pathophysiology of brain ischemia]. Barcelona (ES): Ed. Marge Medica Books; 2007.

27. Castellanos M, Sobrino T, Castillo J. Evolving paradigms for neuroprotection: molecular identification of ischemic penumbra. Cerebrovasc Dis. 2006;21(2):71-79. doi: 10.1159/000091706.

28. Torregrosa G, Salom JB, Jover-Mengual T, Alborch E. Fisiopatologia basica: De la oclusion arterial a la muerte neuronal [Basic pathophysiology: From arterial occlusion to neuronal death]. In: Joan Montaner. Fisiopatologia de la isquemia cerebral [Pathophysiology of brain ischemia]. Barcelona (ES): Ed. Marge Medical Books; 2007.

29. Castillo J, Rodriguez I. Biochemical changes and inflammatory response as markers for brain ischaemia: molecular markers of diagnostic utility and prognosis in human clinical practice. Cerebrovasc Dis. 2004;17(11): 7-18. doi: 10.1159/000074791.

30. Cuenca MD, Brea D, Segura T, Galindo MF, Anton-Martinez D, Agulla J, et al. La inflamacion como agente terapeutico en el infarto cerebral: Respuesta inflamatoria celular y mediadores inflamatorios [Inflammation 
as a therapeutic agent in cerebral infarction: Inflammatory cellular response and inflammatory mediators]. Rev Neurol. 2010;50(6):349-359.

31. Palisano RJ, Hanna SE, Rosembau PL, Russell DJ, Walter SD, Wood EP, et al. Validation of the model gross motor function for children with cerebral palsy. Phys Ther. 2000;80(10):974-985.

32. Lundkvist A, Jarnlo GB, Gummesson C, Nordmark E. Longitudinal construct validity of the GMFM-88 total score and goal total score and the GMFM-66 score in a 5 years follow up study. Phys Ther. 2009;89(4): 342-350. doi: 10.2522/ptj.20080037.

33. Belegui M. Factores asociados a paralisis cerebral Infantil en Veracruz en menores de 6 años de edad [Factors associated with cerebral palsy Children in Veracruz in children under 6 years of age] [thesis]. Veracruz: Universidad Veracruzana; 2013.

34. Peralta C, Leon OS, Xaus C, Prats N, Jalil EC, Planell ES, et al. Protective effect of ozone treatment on the injury associated with hepatic ischemia-reperfusion: antioxidant-prooxidant balance. Free Rad Res. 1999;31:191-196.

35. Calunga JL, Trujillo Y, Menendez S, Zamora Z, Alonso Y, Merino N, et al. Ozone oxidative postconditioning in acute renal failure. J Pharm Pharmacol. 2009;61(2):221-227. doi: 10.1211/jpp/61.02.0012.

36. Al-Dalain SM, Martinez G, Candelario-Jalil E, Menendez S, Re L, Giuliani $A$, et al. Ozone treatment reduces markers of oxidative and endothelial damage in an experimental diabetes model in rats. Pharmaceutical Research. 2001;44(5):391-396. doi: 10.1006/phrs.2001.0867.

37. Leon OS, Menendez S, Merino N, Castillo R, Sam S, Perez L, et al. Ozone oxidative preconditioning: a protection against cellular damage by free radicals. Mediators Inflamm. 1998;1998(7):289-294. doi: 10.1080/09629359890983.

38. Zamora Z, Borrego A, Lopez O, Delgado R, Gonzalez R, Menendez S, et al. Effects of ozone oxidative preconditioning on TNF-a release and antioxidant-prooxidant intracellular balance in mice during endotoxic shock. Mediators Inflamm. 2005;2005(1):16-22. doi: 10.1155/MI. 2005.16.

39. Ajamieh HH, Berlanga J, Merino N, Martinez Sanchez G, , CandelarioJalil E, Menendez S, et al. Role of protein synthesis in the protection conferred by ozone oxidative preconditioning in hepatic ischaemia/ reperfusion. Transpl Int. 2005;18(5):604-612. doi: 10.1111/j. 1432-2277.2005.00101.x.

40. Ajamieh HH, Menendez S, Martinez-Sanchez G, Candelario-Jalil E, Re L, Giuliani $A$, et al. Effects of ozone oxidative preconditioning on nitric oxide generation and cellular redox balance in a rat model of hepatic ischaemia-reperfusion. Liver Int. 2004;24(1):55-62. doi: 10.1111/j. 1478-3231.2004.00885.x.

41. Ajamieh HH, Menendez S, Merino N, Martinez G, Re L, Leon OS. Ischemic and ozone oxidative preconditioning in the protection against hepatic ischemic-reperfusion injury. Ozone Sci Eng. 2003;25(3):241-250.

42. Borrego A, Zamora Z, Gonzalez R, Romay C, Menendez S, Hernandez F, et al. Protection by ozone preconditioning is mediated by antioxidant system in cisplatin-induced nephrotoxicity in rats. Mediators Inflamm. 2004;13(1):13-19. doi: 10.1080/09629350410001664806.

43. Menendez S, Gonzalez R, Ledea OE, Leon OS, Hernandez F, Diaz M. Ozonoterapia: Aspectos basicos y aplicaciones clinicas [Ozone therapy: 
basic aspects and clinical applications]. La Habana: Editorial CENIC; 2008.

44. Calunga JL, Menendez S, Leon R, Chang S, Guanche D, Balbin A, et al. Application of Ozone Therapy in Patients with Knee Osteoarthritis. Ozone Sci Eng. 2012;34:469-475.

45. Dranguet J, Fraga A, Diaz MT, Mallok A, Viebahn R, Fahmy Z, et al. Ozone oxidative postconditioning ameliorates joint damage and decreases pro-inflammatory cytokine levels and oxidative stress in PG/ PS-induced arthritis in rats. Eur J Pharmacol. 2013;714(1-3):318-24. doi: 10.1016/j.ejphar.2013.07.034.

46. Park HJ, Kim CH, Park ES, Park B, Oh SR, Oh MK, et al. Increased GABA-A receptor binding and reduced connectivity at the motor cortex in children with hemiplegic cerebral palsy: a multimodal investigation using 18F-fluoroflumazenil PET, immunohistochemistry, and MR imaging. J Nucl Med. 2013;54(8):1263-9. doi: 10.2967/jnumed. 112.117358.

47. Lee JD, Park HJ, Park ES, Kim DG, Rha DW, Kim EY, et al. Assessment of regional $\mathrm{GABA}(\mathrm{A})$ receptor binding using $18 \mathrm{~F}$-fluoroflumazenil positron emission tomography in spastic type cerebral palsy. Neuroimage. 2007;34(1):19-25. doi: 10.1016/j.neuroimage.2006.09.004.

48. Kopec K. Cerebral palsy: pharmacologic treatment of spasticity. US Pharm. 2008;33(1):22-26.

49. Diaz MT, Fraga A, Dranguet J, Mallok A, Viebahn R, Menendez S, et al. Ozone oxidative postconditioning protects against the injury associated with alcohol withdrawal syndrome in rats. Ozone Sci Eng. 2012;34(6): 425-431.

50. Diaz MT, Fraga A, Dranguet J, Mallok A, Viebahn R, Menendez S, et al. Ozone therapy ameliorates nervous system disorders and oxidative stress in patients during ethanol withdrawal. A pilot study. Ozone Sci Eng. 2012;34(6):432-437. 